\author{
JAKUB MROŻEK \\ Uniwersytet Wrocławski \\ e-mail: j_mrozek@interia.pl
}

\title{
O właściwościach postępowania hybrydowego w regulacji ochrony konkurencji i konsumenta
}

\section{Wstęp}

Współczesną światową gospodarkę tworzy sieć połączonych gospodarek regionalnych o pandemicznym wymiarze oddziaływania. Jest to efekt nie tylko niespotykanego wcześniej rozwoju gospodarczego, jaki nastąpił po zakończeniu II wojny światowej, lecz także zaistnienia na światowym rynku podmiotów gospodarczych o globalnym zasięgu. Implikuje to nowe spojrzenie na termin „wolnego rynku", w którym coraz mniejszą rolę odgrywa tzw. niewidzialna ręka rynku, zaś coraz wyraźniejsze znaczenie mają poszczególne regulacje sektorowe.

Wraz z poszerzeniem obszaru zdominowanego przez regulacje sektorowe powstają specjalistyczne instytucje publiczne (państwowe, międzynarodowe lub ponadnarodowe), które zostały wyposażone w instrumenty o charakterze administracyjnoprawnym, ergo narzędzia, dzięki którym podmioty te mogą we władczy — względem podmiotów gospodarczych — sposób realizować swoje zadania. Polskimi przykładami takich instytucji są przede wszystkim: Komisja Nadzoru Finansowego, Prezes Urzędu Komunikacji Elektronicznej, Prezes Urzędu Regulacji Energetyki, Prezes Urzędu Transportu Kolejowego, Prezes Urzędu Lotnictwa Cywilnego oraz - najistotniejszy z uwagi na tematykę niniejszego artykułu Prezes Urzędu Ochrony Konkurencji i Konsumenta (UOKiK).

Z wyjątkiem Komisji Nadzoru Finansowego, wspólną cechą charakteryzującą procedowanie ww. organów jest niepełna - jedynie częściowa — regulacja w przepisach administracyjnoprawnych. W pozostałym zaś zakresie postępowanie to jest regulowane poprzez przepisy Kodeksu postępowania cywilnego, ergo 
przepisy cywilnoprawne ${ }^{1}$. Powyższy, administracyjno-cywilny model postępowania w nauce prawa jest określany mianem „mieszanego” lub „hybrydowego"2 modelu postępowania.

\section{Porównanie klasycznego postępowania administracyjnego z postępowaniem hybrydowym (administracyjno-cywilnym)}

Najważniejsza różnica między „klasycznym”3 modelem postępowania administracyjnego a modelem „hybrydowym” wiąże się z odmiennym zadaniem i rolą podmiotów władzy sadowniczej, jaką odgrywają one w poszczególnych schematach procesowych.

Administracyjny model procesowy zakłada przede wszystkim dwuinstancyjność ${ }^{4}$ postępowania, odbywającego się wyłącznie w sferze organów administracji

1 Tym samym w powyższym zakresie — zastępowania regulacji administracyjnych procesowymi regulacjami cywilnymi - następuje tzw. zjawisko dekodyfikacji. Szeroko na ten temat piszą m.in.: M. Gajda-Durlik, Dekodyfikacja postępowania administracyjnego, [w:] Koncepcja systemu prawa administracyjnego, red. J. Zimmermann, Warszawa 2007, s. 517 n.; Z. Kmieciak, Zarys teorii postępowania administracyjnego, Warszawa 2014, s. 69-81.

2 Określenie to jest stosunkowo nowe, pierwszy raz zostało bowiem wykorzystane przez Zbigniewa Kmieciaka w: idem, Postepowanie w sprawach ochrony konkurencji a koncepcja procedury hybrydowej, „Państwo i Prawo” 2002, z. 4, s. 46-47.

3 Model ten obejmuje zarówno postępowanie przed organami administracji publicznej (postępowanie stricte administracyjne), jak i przed sądem administracyjnym (postępowanie sądowoadministracyjne). Warto też dodać, że bardzo interesujące rozważania na temat ewolucji podjęcia ,,postępowania administracyjnego" zaprezentował Z. Kmieciak; zob. idem, Zarys teorii postepowania..., s. $17 \mathrm{n}$.

${ }^{4}$ Wynika to z art. 15 i konkretyzującego go art. 127 §1-2 Kodeksu postępowania administracyjnego (tekst jedn. Dz.U. z 2016 r. poz. 23 ze zm.; dalej: k.p.a.). Wyjątek, jaki ustanawia art. 127 § 3 k.p.a., pozwala jednak stwierdzić, że postępowanie administracyjne nie zawsze będzie postępowaniem instancyjnym. Wynika to z tezy, jaką stawia Jan Zimmermann, podnoszący, że w sytuacji gdy działa jeden organ, nie może on być nazwany instancją. Na tej podstawie, zdaniem tego autora, o pojęciu instancji można mówić dopiero, kiedy prawo przewiduje działanie przynajmniej dwóch organów powiązanych elementem ustrojowo-organizacyjnym. Zob. idem, Administracyjny tok instancji, Kraków 1986, s. 11-12. Niezależnie od tego należy wskazać, że zasada dwuinstancyjności w postępowaniu administracyjnym jest nieprzypadkowa, gdyż implikuje normę zawartą w art. 78 Konstytucji RP, która z omawianej cechy czyni zasadę konstytucyjną (a więc również prymarną). Warto również nadmienić, że w nauce prawa konstytucyjnego wskazuje się, że dopuszczone ww. przepisem wyjątki nie tylko nie mogą prowadzić do naruszenia innych norm konstytucyjnych, lecz także nie mogą prowadzić do przekreślenia samej zasady ogólnej. Dlatego też odstępstwo od reguły wyznaczonej treścią art. 78 Konstytucji każdorazowo powinno być podyktowane szczególnymi okolicznościami usprawiedliwiającymi pozbawienie stronie środków odwoławczych. Zob. L. Garlicki, Komentarz do art. 78 Konstytucji RP, [w:] Konstytucja Rzeczypospolitej Polskiej, red. L. Garlicki, t. 5, Warszawa 2007, s. 10; B. Adamiak, 
publicznej (będącej przestrzenią władzy wykonawczej). Dopiero zaś po wykorzystaniu przysługujących stronie środków odwoławczych — wyczerpaniu administracyjnego toku instancji — następuje możliwość transponowania określonego rozstrzygnięcia administracyjnego na grunt władzy sądowniczej - w celu rozpoznania przez sąd administracyjny. Powyższa transpozycja nie powoduje jednak sytuacji, w wyniku której wraz z przekazaniem sprawy do sądu administracyjnego przechodzą na tenże podmiot kompetencje do jej rozstrzygnięcia. W omawianym modelu rolą sądu administracyjnego jest bowiem (jedynie) weryfikacja — kontrola danego rozstrzygnięcia administracyjnego, która będzie dokonywana w sposób kasacyjny ${ }^{5}$, pod kątem jego legalności. Tym samym sąd administracyjny, rozpoznając daną sprawę, ergo kontrolując określone rozstrzygnięcie (bądź inny efekt działalności) organu administracji publicznej, będzie badał wyłącznie to, czy zostało ono wydane zgodnie z przepisami prawa ${ }^{6}$. Oznacza to również, że sąd administracyjny nie będzie weryfikował pozostałych zagadnień ogólnie związanych $\mathrm{z}$ administrowaniem (np. celowości, rzetelności), nawet jeśli ostatecznie miały one wpływ na podjęcie danego rozstrzygnięcia. Ma to fundamentalne znaczenie, gdyż mimo wspomnianej transpozycji sprawy (z obszaru egzekutywy do judykatury) $\mathrm{w}$ omawianym modelu nie następuje przekazanie kompetencji stanowiących essentialia negotii poszczególnych władz, tzn. przekazania uprawnień administracyjnych przynależnych organowi wykonawczemu do sądu administracyjnego.

Mając to na uwadze, należy stwierdzić, że powyższy model bardzo harmonijnie nawiązuje do - zadekretowanej w art. 10 ust. 1 oraz dodatkowo doprecyzowanej w art. 173 Konstytucji Rzeczypospolitej Polskiej z dnia 2 kwietnia $1997 \mathrm{r}^{7}$ — zasady trójpodziału władzy. Zakłada ona rozdział pomiędzy legislatywą i egzekutywą oraz szczególną separację judykatury ${ }^{8}$, implikującą pozbawienie jej jakichkolwiek powiązań organizacyjnych z pozostałymi władzami.

Zupełnie inaczej prezentuje się rola sądu (ergo podmiotu władzy sądowniczej) $\mathrm{w}$ modelu hybrydowym. Wiąże się to przede wszystkim z rezygnacją

[w:] Prawo procesowe administracyjne, red. R. Hauser, Z. Niewiadomski, A. Wróbel, „System Prawa Administracyjnego" 9, Warszawa 2014, s. 220 n.

5 Jest to konsekwencja modelu sądownictwa administracyjnego, jaki został przyjęty w Polsce. Więcej na ten temat, z uwzględnieniem perspektywy o historycznej, piszą Barbara Adamiak i Janusz Borkowski; zob. B. Adamiak, J. Borkowski, Postepowanie administracyjne i sadowoadministracyjne, Warszawa 2014, s. 68 n.

${ }^{6}$ Szerzej o różnicy między sądowoadministracyjnym sprawowaniem kontroli nad działalnością administracji publicznej a załatwieniem sprawy będącym wynikiem działania administracji publicznej piszą Roman Hauser oraz Małgorzata Masternak-Kubiak; zob. R. Hauser, M. Masternak-Kubiak, [w:] Konstytucyjne podstawy funkcjonowania administracji publicznej, red. R. Hauser, Z. Niewiadomski, A. Wróbel, „System Prawa Administracyjnego” 2, Warszawa 2012, s. 404 n.

7 Dz.U. Nr 78, poz. 483 ze zm.

8 Należy to wiązać z doniosłym charakterem funkcji tejże władzy — przede wszystkim sprawowaniem wymiaru sprawiedliwości, a ponadto kontrolą zgodności ustaw, rozporządzeń i umów międzynarodowych pod kątem zgodności z Konstytucją oraz orzekaniem w zakresie odpowiedzialności konstytucyjnej w stosunku do najważniejszych osób w państwie. 
z dwuinstancyjności postępowania. W modelu tym rozstrzygnięcia organu administracji publicznej podlegają natychmiastowej weryfikacji przez sąd. Sądem tym nie jest jednak sąd administracyjny, lecz sąd powszechny. Podkreślenie tego faktu jest niezwykle ważne, gdyż wyroki sądów powszechnych — inaczej niż sądów administracyjnych - nie są kasacyjne i mają merytoryczny charakter, orzekając co do istoty sprawy (praw i obowiązków stron postępowania). Innymi słowy, „twórczo" rozstrzygają przekazany im do rozpoznania spór prawny. Tym samym także $\mathrm{w}$ omawianym schemacie procesowym wniesienie środka zaskarżenia od rozstrzygnięcia danego organu administracji publicznej powoduje — wskutek natychmiastowego przejęcia sprawy przez sąd powszechny — transformację materialnego charakteru sprawy, która przestaje być sprawą administracyjną, de facto stając się - w związku z tym, iż będzie rozpoznawana w oparciu o przepisy Kodeksu postępowania cywilnego ${ }^{9}$ - sprawą cywilną (zob. art. 1 k.p.c.).

Powyższe wskazanie pozostaje niezwykle istotne, albowiem treścią sprawy administracyjnej, jak słusznie podnosi Jan Zimmermann, jest konkretyzacja prawa materialnego, jaka ma miejsce w momencie wydania decyzji; dlatego też nie jest to spór wyrosły na gruncie skonkretyzowanego stosunku prawnego, a jedynie sprawa stosunku prawnego ${ }^{10}$. W przypadku sprawy cywilnej mamy do czynienia ze sprawą ze stosunku prawnego, której celem rozpoznania może być rozwiązanie abstrakcyjnej normy prawa materialnego poprzez jej zadeklarowanie bądź - w przypadku orzeczeń konstytutywnych, co do których prawo materialne (cywilne) nie zawiera $\mathrm{w}$ danym przedmiocie żadnego rozwiązania abstrakcyjnego przez samodzielne stworzenie lub zmianę istniejącego dotąd stanu prawnego ${ }^{11}$.

Co więcej, w przeciwieństwie do klasycznego, w modelu hybrydowym wraz z przejęciem sprawy przez sąd na podmiot ten przechodzą również kompetencje konieczne do jej rozstrzygnięcia. Jego decyzje zapadają jednak w formie orzeczeń sądowych, podejmowane są niejako „zastępczo”, za organ administracji publicznej. Można więc również przyjąć, że na omawiany etapie postępowania sąd staje się ,judykacyjnym podmiotem administrującym”. Nie będzie on bowiem organem administracji publicznej, a co za tym idzie - nie będzie stosował uregulowanej w art. 7 k.p.a. zasady prawdy obiektywnej, nakazującej z urzędu lub na wniosek stron podejmować wszelkie czynności niezbędne do dokładnego wyjaśnienia stanu faktycznego oraz do załatwienia sprawy, mając na względzie interes społeczny i słuszny interes obywateli; lecz podczas procedowania będzie kierował się rządzącymi postępowaniem cywilnym zasadami prawdy materialnej (art. 3 k.p.c.),

9 Tekst jedn. Dz.U. z 2016 r. poz. 1822 ze zm. (dalej: k.p.c.).

10 Zob. Koncepcja systemu prawa..., s. 13.

11 Szerzej na ten temat piszą m.in.: A. Łazarska, Gwarancje swobody sumienia sędziego w procesie cywilnym, „Studia Prawnicze” 2008, z. 3 (177), s. 41 n.; M. Waligórski, Proces cywilny. Funkcja i struktura, Warszawa 1947, s. 36-37. Por. cel rozpoznania sprawy cywilnej, jaki prezentuje T. Ereciński, [w:] Środki zaskarżenia, red. J. Gudowski, „System Prawa Procesowego Cywilnego" 3, cz. 1, Warszawa 2013, s. 33. 
swobodnej oceny dowodów (art. 233 k.p.c.) oraz związania sądu wyłącznie mocą wyroku skazującego (art. 11 k.p.c.).

Nie wdając się w analizę zgodności ww. modelu z Konstytucją ${ }^{12}$, trzeba podkreślić bardzo istotny aspekt powyższego schematu procesowego. Mianowicie, biorąc pod uwagę prymarną zasadę procesu cywilnego — zakładającą równość podmiotów toczących spór sądowy — należy postawić tezę, że — inaczej niż w przypadku sporu sądowoadministracyjnego — w momencie przejęcia przez sąd powszechny sprawy (dotychczas administracyjnej) państwo, reprezentantem, którego staje się organ administracji publicznej, niejako traci, na rzecz sądu, dotychczasowy przymiot w postaci imperium. Należy bowiem zauważyć, że orzekający co do istoty sprawy sąd powszechny nie tylko nie jest związany, lecz wręcz jest władny (nawet w całości) odrzucić cały materiał dowodowy stanowiący podstawę dla rozstrzygnięcia danego organu regulacji sektorowej. To zaś, wobec wspomnianej wcześniej rządzącej zasady prawdy materialnej, oznacza, że wyrok sądu powszechnego może zapaść w całkowitym oderwaniu od wcześniejszego rozstrzygnięcia właściwego organu regulacji sektorowej, de facto czyniąc zbędnym jego istnienie.

\section{Konstytucyjne uwarunkowania postępowania przed Prezesem UOKiK}

Powyższa analiza pozostaje szczególnie istotna, wziąwszy pod uwagę specyfikę postępowania w sprawie ochrony konkurencji i konsumenta (postępowanie przed Prezesem UOKiK). Postępowanie to bowiem nosi znamiona regulacji konstytucyjnej, co jest konsekwencją konstrukcji art. 76 Konstytucji. W przepisie tym in principio zadekretowano, że ochrona konsumentów przed działaniami zagrażającymi ich zdrowiu, prywatności, bezpieczeństwu oraz aktywności, noszącą znamiona nieuczciwych praktyk rynkowych jest jednym z zadań władzy publicznej.

Z uwagi na fakt, iż Konstytucja nie wyjaśnia znaczenia pojęcia „władzy publicznej”, termin ten został ostatecznie dekodowany na gruncie orzecznictwa Trybunału Konstytucyjnego (TK). W wyroku z 4 grudnia 2001 r. ${ }^{13}$ Trybunał orzekł, że pojęcie „władzy publicznej” należy rozumieć jako wszystkie konstytucyjne władze - legislatywę, egzekutywę ${ }^{14}$, judykaturę oraz niedające się jednoznacznie sklasyfikować organy kontroli państwowej i ochrony prawa ${ }^{15}$. Jest to wskazówką interpre-

12 Szeroko tę problematykę opisuje J. Mrożek, Wypieranie prawa administracyjnego przez prawo cywilne a konstytucyjny trójpodziat władzy, [w:] Tendencje rozwojowe prawa administracyjnego, red. E. Kruk, G. Lubeńczuk, T. Drab, Lublin 2017, s. 59 n.

13 Wyrok TK z dnia 4 grudnia 2001 r., sygn. SK 18/00, OTK ZU 2001/8, poz. 256.

14 W tym także samorząd terytorialny, na co jednoznacznie wskazuje art. 163 Konstytucji.

15 Zob. J. Trzciński, Komentarz do art. 173 Konstytucji RP, [w:] Konstytucja Rzeczpospolitej Polskiej. Komentarz, red. L. Garlicki, t. 1, Warszawa 1999, s. 1; A. Sylwestrzak, Nowe interpretacje 
tacyjną, pozwalającą przyjąć tezę, że realizacja omawianego przepisu ma zakładać wspólną aktywność podmiotów wchodzących w skład ww. rodzajów władz. Należy jednak zaznaczyć, iż wspomniana wspólna aktywność w realizacji art. 76 Konstytucji nie może odbywać się w oderwaniu od pozostałych regulacji ustawy zasadniczej.

Równie istotna w uzyskaniu pełnego znaczenia omawianego przepisu jest wykładnia systemowa (argumentum a rubica), polegająca na ustalaniu jego właściwego znaczenia na podstawie jego usytuowania w systemie prawa. Leszek Garlicki wskazuje w związku z tym, że przedmiotowy artykuł należy do grupy przepisów określanych jako zasady polityki państwa ${ }^{16}$, ergo regulacji prawnych nakładających, niezwiązane z konkretnymi uprawnieniami jednostek, obowiązki na władze publiczne ${ }^{17}$. Na tej podstawie można stwierdzić, że wspomniane współdziałanie podmiotów władzy publicznej w zakresie realizacji omawianego przepisu należy zrozumieć, po pierwsze, po stronie władzy ustawodawczej jako obowiązek uchwalenia ustawy regulującej, stosownie do art. 76 zd. 2 Konstytucji, zakres ochrony udzielanej przez władz publiczne m.in. w zakresie ochrony konsumentów przed nieuczciwymi praktykami rynkowymi. W tym zakresie mieścić się będzie również utworzenie specjalistycznego organu (jakim niewątpliwie jest Prezes UOKiK) odpowiadającego za urzeczywistniania tejże ochrony. Po drugie, po stronie władzy wykonawczej — z uwagi na to, iż regulacja ta jest jedną z zasad polityki państwa, władzy wykonawczej, którą należy w tym wypadku utożsamiać z organami administracji rządowej, gdyż to one wcielają w życie zasady polityki państwowej ${ }^{18}$ - umożliwienie Prezesowi UOKiK działalności służącej realizacji art. 76 Konstytucji, w zgodzie z zasadą trójpodziału władzy (tj. w sposób niezależny zarówno od władzy ustawodawczej, jak i sądowniczej). Po trzecie, umożliwienie podmiotom objętym zakresem działalności Prezesa UOKiK dochodzenia — stosownie do art. 77 ust. 2 oraz art. 22 Konstytucji - swoich roszczeń przed niezależnym i niezawisłym sądem. Wobec zaś faktu, że organem realizującym omawiane zasady polityki państwa będzie organ administracji rządowej, ergo organ administracji publicznej, należy — w ślad za art. 184 Konstytucji — objąć działalność Prezesa UOKiK kontrolą sądów administracyjnych.

Niemożliwa do akceptacji jest bowiem teza, że realizacja art. 76 Konstytucji umożliwia przejęcie tegoż zadania polityki państwowej wyłącznie przez sądy. Działalność ochronna przed nieuczciwymi praktykami rynkowymi z samej swojej natury jest aktywnością egzekutywą, a więc aktywnością z zakresu imperium o ad-

podziału władz, [w:] Czas a trwanie idei politycznych i prawnych, red. K. Chojnicka, A. Citkowska-Kimla, W. Kozub-Ciembroniewicz, Warszawa 2008, s. 124-125.

16 Prócz art. 76 L. Garlicki do ww. grupy zalicza również art. 65 ust. 5, art. 68 ust. 4-5, art. 71 ust. 1 zd. 1 , art. 74 ust. $1-2,4$ oraz art. 75 Konstytucji.

17 L. Garlicki, Komentarz do Rozdziału II Konstytucji RP: , Wolności, prawa i obowiazki człowieka i obywatela", [w:] Konstytucja Rzeczpospolitej Polskiej. Komentarz, red. L. Garlicki, t. 2, Warszawa 2003, s. 4.

18 Zob. art. 146 ust. 3 w zw. z ust. 1-2 i 4 pkt 3 Konstytucji. 
ministracyjnym charakterze ${ }^{19}$. Truizmem będzie zatem stwierdzenie, że przedmiotowa działalność (podobnie jak ta podejmowana w związku z art. 65 ust. 5, art. 68 ust. 3-5, art. 70 ust. 5 oraz art. 74 ust. 1 Konstytucji) wymaga inicjowania działań $\mathrm{z}$ urzędu, a więc aktywności co do zasady ${ }^{20}$ nieznanej władzy sądowniczej.

\section{Konsekwencje postępowania hybrydowego}

W wypadku spraw z zakresu ochrony konkurencji i konsumenta konsekwencje - czyli utrata imperium ( $\mathrm{tj}$. zdolności administrowania) — jakie powoduje postępowanie hybrydowe, doskonale scharakteryzował Bohdan Zdziennicki w zdaniu odrębnym do wyroku TK z dnia 31 stycznia 2005 r. ${ }^{21}$, stwierdzając, że: skarżący niezadowolony z decyzji Prezesa UOKiK ma prawo szukać „sprawiedliwości” w Sądzie Okręgowym w Warszawie - sądzie ochrony konkurencji i konsumentów. Sam fakt odwołania wskazuje zresztą, że w sensie subiektywnym strona straciła w swojej sprawie zaufanie co do bezstronności i wiedzy fachowej Prezesa i stąd chce w miejsce rozstrzygnięcia administracyjnego uzyskać rozstrzygnięcie sądowe ${ }^{22}$.

Dalej sędzia ten krytycznie odniósł się do interpretacji art. $479^{31 a} \S 3$ k.p.c., zakładającej „niczym nieograniczone uprawnienia sądu ochrony konkurencji i konsumenta do uchylenia decyzji Prezesa Urzędu Ochrony Konkurencji i Konsumentów i przekazania mu sprawy do ponownego rozpatrzenia"23, które jego zdaniem mogą też prowadzić do wydawania wiążących dla organu władzy wykonawczej „pisemnych poleceń” (zawartych w pisemnym uzasadnieniu wyroku uchylającego decyzję i przekazujących sprawę do ponownego rozpatrzenia). Określenie sposobu załatwienia sprawy należy jednak do ustawowych kompetencji Prezesa UOKiK ${ }^{24}$, co pozostaje wysoce dyskusyjne w kontekście konstytucyjnego trójpodziału władzy. W końcowych zaś uwagach do powyższego zdania odrębnego B. Zdziennicki stwierdził dysfunkcjonalność tegoż model postępowania.

Nie sposób zaprzeczyć trafności powyższego stanowiska, faktycznie bowiem odwołanie się od decyzji Prezesa UOKiK, wobec uprawnień sądu ochrony konkurencji i konsumenta, nie tylko stawia pod znakiem zapytania ratio legis istnienia tegoż organu, lecz także niejako zaprzecza bezstronności oraz odmawia specjalistycznego charakteru temu organowi. Konsekwencją tego jest sprowadzenie roli

19 Tzn. zakładającym nierówność podmiotów oraz wyposażenie organu administracji publicznej w tzw. władztwo.

${ }^{20}$ Wyjątkiem jest np. postępowanie w razie zaginięcia lub zniszczenia akt.

21 Wyrok TK z dnia 31 stycznia 2005 r., sygn. SK 27/03, OTK-A 2005/1, poz. 8, s. 86. Jest to również pierwsze orzeczenie TK, w którym tak jednoznacznie negatywnie odniesiono się do omawianej procedury z perspektywy zasady trójpodziału władzy.

22 Ibidem.

23 Ibidem, s. 87.

24 Ibidem, s. 88. 
Prezesa UOKiK wyłącznie do jednej ze stron sporu cywilnego. To zaś budzi wątpliwości w zakresie (pełnej) realizacji art. 76 Konstytucji, który — jak już zaakcentowano — zakłada współdziałanie w jego urzeczywistnieniu zarówno władzy sądowniczej, ustawodawczej, jak i wykonawczej.

Niezależnie od tego, sytuacja, jaką kreuje postępowanie hybrydowe — w którym organy wykonawcze $\mathrm{w}$ postępowaniu realizowanym $\mathrm{w}$ ramach ich uprawnień (dokonywanych w celu realizacji zasad polityki państwowej) tracą element imperium, stając się jedną ze stron sporu cywilnoprawnego — otwiera drogę do budzących jeszcze większe wątpliwości zgodności z ustawą zasadniczą tzw. międzynarodowych arbitraży gospodarczych. Mowa tu o funkcjonujących w oparciu o umowy międzynarodowe quasi-organach sądowych, rozpoznających m.in. sprawy z zakresu ochrony konkurencji i konsumenta. Cechą swoistą powyższych postępowań arbitrażowych (często określanych jako sądy lub trybunały) jest to, że nie rozpoznają one spraw na linii sygnatariuszy danej umowy (państwo versus państwo), lecz pomiędzy państwem-sygnatariuszem a podmiotem gospodarczym korzystającym z postanowień danej umowy międzynarodowej. Kolejną cechą charakteryzującą ww. postępowania jest to, że mogą one dotyczyć nie tyle faktycznych naruszeń postanowień danej umowy, lecz jedynie potencjalnych naruszeń. Co więcej, procedura rozpoznania spraw odbywa się w całkowitym oderwaniu od porządku krajowego danego państwa (nie wyłączając postanowień konstytucyjnych). To zaś, w sytuacji negatywnego dla państwa rozstrzygnięcia, sprowadza się do tego, że traci ono prawo do swobodnego kształtowania swojego porządku prawnego, gdyż wystarczające jest, aby projektowane przepisy stwarzały jedynie ryzyko naruszenia postanowień umowy, żeby danemu państwu można było zarzucić łamanie postanowień danej umowy.

\section{Wnioski}

Mając na uwadze zaprezentowane argumenty, należy stwierdzić, że utrata przez organ administracji publicznej, w toku toczącego się postępowania hybrydowego, uprawnień z zakresu imperium (które są przejmowane przez podmiot władzy sądowniczej) stanowi o poważanych wątpliwościach co do zgodności z zapisami ustawy zasadniczej. Toteż, w ślad za wyrokiem TK z 2 lipca $2003 \mathrm{rr}^{25}$, trzeba zwrócić uwagę, że działalność publiczna związana z branżowymi rynkami regulowanymi dotyczy bardzo złożonych kwestii ekonomiczno-organizacyjnych. Wymaga więc nie tylko specjalistycznej wiedzy, lecz także branżowego doświadczenia ${ }^{26}$. Obejmuje bowiem szerokie spektrum działań mających zarówno

25 Wyrok TK z dnia 2 lipca 2003 r., sygn. K 25/01, OTK-A 2003/6, poz. 60, s. 780-784.

26 Ibidem, s. 781. 
publicznoprawny charakter, jak i charakter prywatnoprawny, a miejscami nawet penalny ${ }^{27}$. Dlatego niemożliwa do akceptacji jest również sytuacja utraty przez podmioty władzy wykonawczej uprawnień do władczego kształtowania stosunku prawnego, gdyż prowadzi to do ubezskutecznienia działań tychże organów, jednocześnie otwierając drogę do jeszcze głębiej ingerujących w sferę imperium międzynarodowych postępowań arbitrażowych.

Konkludując, dysfunkcjonalność postępowania hybrydowego wymaga jego eliminacji z porządku prawnego. W jego miejsce należy wprowadzić regulacje oparte na klasycznym modelu administracyjnym. Doskonałym przykładem, który mógłby stanowić wzorzec dla nowych regulacji, jest model postępowania działający na podstawie Ustawy z dnia 21 lipca 2006 r. o nadzorze nad rynkiem finansowym ${ }^{28}$ - przed Komisją Nadzoru Finansowego (KNF). Postępowanie to jednak, inaczej niż postępowanie przed Prezesem UOKiK, toczy się w oparciu o przepisy k.p.a., z zachowaniem lex specialis ${ }^{29}$. Wobec braku odmiennych postanowień ostateczne rozstrzygnięcia KNF będą mogły zostać zaskarżone do sądu administracyjnego. Tym samym procedura ta w pełni zachowuje konstytucyjne standardy, a co za tym idzie - może zostać uznana za wzorzec dla analogicznych regulacji przed organami regulacji sektorowej.

\title{
Peculiarities of hybrid proceedings in the regulation of competition and consumer protection
}

\author{
Summary
}

This article describes the issue of replacing administrative regulations with civil law regulations. This is a multi-faceted problem, so the paper will focus on the example of the so-called hybrid proceedings, pending before the President of the Office of Competition and Consumer Protection. In the article, a brief comparison of the hybrid proceedings approach to classical administrative proceedings was initially conducted, pointing out that there was considerable uncertainty about compliance with the Constitutional division of power. The analysis of the proceedings before the President of the OCCP was presented, because of its links with the Constitution, indicating the disfunctionality of that authority at the time of the appeal. In the final section, research proposals and proposed changes were introduced, which consisted entirely of abandoning the hybrid model to the classic administrative model.

Keywords: President of the OCCP, administrative regulations, civil law regulations, division of power, hybrid proceedings.

\footnotetext{
27 Ibidem.

28 Dz.U. z 2016 r. poz. 174 ze zm.; dalej: u.n.r.f.

29 Należy do nich m.in. zastrzeżenie zawarte w art. 11 ust. 6 u.n.r.f.
} 